\title{
Facile synthesis of flower like copper oxide and their application to hydrogen peroxide and nitrite sensing
}

\author{
Li Zhang ${ }^{*}$, Feifei Yuan, Xiaohu Zhang and Liming Yang
}

\begin{abstract}
Background: The detection of hydrogen peroxide $\left(\mathrm{H}_{2} \mathrm{O}_{2}\right)$ and nitrite ion $\left(\mathrm{NO}_{2}^{-}\right)$is of great important in various fields including clinic, food, pharmaceutical and environmental analyses. Compared with many methods that have been developed for the determination of them, the electrochemical detection method has attracted much attention. In recent years, with the development of nanotechnology, many kinds of micro/nano-scale materials have been used in the construction of electrochemical biosensors because of their unique and particular properties. Among these catalysts, copper oxide (CuO), as a well known p-type semiconductor, has gained increasing attention not only for its unique properties but also for its applications in many fields such as gas sensors, photocatalyst and electrochemistry sensors. Continuing our previous investigations on transition-metal oxide including cuprous oxide and $\alpha-\mathrm{Fe}_{2} \mathrm{O}_{3}$ modified electrode, in the present paper we examine the electrochemical and electrocatalytical behavior of flower like copper oxide modified glass carbon electrodes (CuO/ GCE).

Results: Flower like copper oxide (CUO) composed of many nanoflake was synthesized by a simple hydrothermal reaction and characterized using field-emission scanning electron microscopy (FE-SEM) and X-ray diffraction (XRD). $\mathrm{CuO}$ modified glass carbon electrode (CUO/GCE) was fabricated and characterized electrochemically. A highly sensitive method for the rapid amperometric detection of hydrogen peroxide $\left(\mathrm{H}_{2} \mathrm{O}_{2}\right)$ and nitrite $\left(\mathrm{NO}_{2}^{-}\right)$was reported.

Conclusions: Due to the large specific surface area and inner characteristic of the flower like $\mathrm{CuO}$, the resulting electrode show excellent electrocatalytic reduction for $\mathrm{H}_{2} \mathrm{O}_{2}$ and oxidation of $\mathrm{NO}_{2}^{-}$. Its sensitivity, low detection limit, fast response time and simplicity are satisfactory. Furthermore, this synthetic approach can also be applied for the synthesis of other inorganic oxides with improved performances and they can also be extended to construct other micro/nano-structured functional surfaces.
\end{abstract}

\section{Background}

The detection of hydrogen peroxide $\left(\mathrm{H}_{2} \mathrm{O}_{2}\right)$ is of great important in various fields including clinic, food, pharmaceutical and environmental analyses, because $\mathrm{H}_{2} \mathrm{O}_{2}$ is a chemical threat to the environment and the production of enzymatic reactions [1]. Many methods have been developed for the determination of $\mathrm{H}_{2} \mathrm{O}_{2}$, such as titrimetry [2], spectrophotometry [3], chromatography [4] and chemiluminescence [5]. Compared with the

\footnotetext{
*Correspondence: lizhang3@mail.ahnu.edu.cn

College of Chemistry and Materials Science, Anhui Key Laboratory of Functional Molecular Solids, Anhui Normal University, Wuhu 241000, P. R.
} China above detection methods, the electrochemical detection of $\mathrm{H}_{2} \mathrm{O}_{2}$ was introduced to achieve a low detection limit and a low cost compared with the other detection methods. In recent years, with the development of nanotechnology, many kinds of micro/nano-scale materials have been used in the construction of electrochemical biosensors because of their unique and particular properties. A number of excellent reports have focused on the electrochemical determination of $\mathrm{H}_{2} \mathrm{O}_{2}$ utilizing noble metals including gold [6], silver [7], platinum [8,9], palladium [10], and graphene-Pt nanoparticle hybrid material [11], transition metals and their oxides or complexes, such as $\mathrm{MnO}_{2}$ [12], Mn-nitrilotriacetate acid nanowires [13], \\ () Chemistry Central}


$\mathrm{CuO}$ nanoparticles [14], $\mathrm{Cu}-\mathrm{Ni}(\mathrm{OH})_{2}$ [15], layered double hydroxide [16], prussian blue [17], conducting polymers [18] and nanocomposite $\mathrm{MnO}_{2} / \mathrm{MWNTs}, \mathrm{Ag} / \mathrm{GO}$ $[19,20]$, as well as enzyme and protein modified electrodes $[21,22]$. The low detection limit achieved with such platforms especially metal nanoparticle based electrodes is due to the enhancement in the signal-to-noise $(\mathrm{S} / \mathrm{N})$ ratio and increased mass transport to the electrode surface $[11,21]$. Although some chemically modified electrodes have been proposed to reduce the large overpotential required for the direct oxidation or reduction of $\mathrm{H}_{2} \mathrm{O}_{2}$, it is still interesting to develop new materials with high efficiency and small dimensions for the detection of $\mathrm{H}_{2} \mathrm{O}_{2}$.

Like $\mathrm{H}_{2} \mathrm{O}_{2}$, nitrite ion $\left(\mathrm{NO}_{2}^{-}\right)$is another often studied analyte in various fields including clinic, food, and environmental analyses because its excess level in the blood has been proved to lead to haemoglobin oxidation [23-26]. Also it may interact in the stomach with amines and amides forming highly carcinogenic $\mathrm{N}$-nitrosamine, many of which are known to be carcinogens $[27,28]$. Therefore, $\mathrm{NO}_{2}^{-}$determination is important for environment security and public health. Although $\mathrm{NO}_{2}^{-}$is electroactive at carbon electrodes, its oxidation requires undesirably high overpotential and the voltammetric determination of it suffers from interference from other compounds. In order to improve the selectivity of $\mathrm{NO}_{2}^{-}$ sensor, the operating potential should be efficiently lowered. Modified electrodes with suitable electro-catalysts on the surface of carbon electrodes can achieve the purpose with an improved oxidation response of $\mathrm{NO}_{2}^{-}$[29-31].

Metal oxide electrodes possess some unique electrochemical properties compared to metal ones. Their advantages include enhancement of reaction rate due to redox couples of oxide species of two different states, as well as weak adsorption or complete exclusion of hydrogen species on an oxide surface [31]. Among these catalysts, copper oxide $(\mathrm{CuO})$, as a well known p-type semiconductor, has gained increasing attention not only for its unique properties but also for its applications in many fields such as gas sensors, photocatalyst and electrochemistry sensors [30,32-36]. Continuing our previous investigations on transition-metal oxide including cuprous oxide and $\alpha-\mathrm{Fe}_{2} \mathrm{O}_{3}[37,38]$ modified electrode, in the present paper we examine the electrochemical and electrocatalytical behavior of flower like copper oxide modified glass carbon electrodes (CuO/GCE). $\mathrm{CuO}$ was characterized by Powder X-ray diffraction (XRD), Field emission scanning electron microscopes (SEM) and cyclic voltammetry (CV) measurements. The electrochemical properties of the modified electrode were evaluated with regards to electrocatalytical reduction of $\mathrm{H}_{2} \mathrm{O}_{2}$ and electrocatalytical oxidation of $\mathrm{NO}_{2}^{-}$.

\section{Experimental}

\section{Reagents and apparatus}

$\mathrm{Cu}\left(\mathrm{NO}_{3}\right)_{2} \cdot 3 \mathrm{H}_{2} \mathrm{O}, \mathrm{NH}_{3} \cdot \mathrm{H}_{2} \mathrm{O}$ and hexamethylenetetramine was purchased from Shanghai Chemical Reagent Factory (Shanghai, China). $\mathrm{NaNO}_{2}$ and $30 \% \mathrm{H}_{2} \mathrm{O}_{2}$ solution was purchased from Beijing Chemical Reagent Factory (Beijing, China). All of the other chemicals used were analytical grade and used without further purification. Double-distilled water was used for preparation of buffer and standard solutions. All solutions were purged with high-purity nitrogen for at least $30 \mathrm{~min}$ to remove oxygen. $\mathrm{NaNO}_{2}$ and $\mathrm{H}_{2} \mathrm{O}_{2}$ solution was diluted daily before the electrochemical measurements.

Electrochemical experiments were performed with CHI 440a electrochemical analyzer (ChenHua Instruments Co. Ltd., Shanghai, China) with a conventional three-electrode cell. The $\mathrm{CuO} / \mathrm{GCE}$, an $\mathrm{Ag} / \mathrm{AgCl}$ and a platinum electrode was used as the working electrode, the reference and the auxiliary electrode, respectively.

\section{Synthesis of flower like CuO}

In a typical synthesis, $0.7345 \mathrm{~g} \mathrm{Cu}\left(\mathrm{NO}_{3}\right)_{2} \cdot 3 \mathrm{H}_{2} \mathrm{O}$ and $0.8230 \mathrm{~g}$ hexamethylenetetramine (HMT) were dissolved into $25 \mathrm{ml}$ distilled water under magnetic stirring. After $5.0 \mathrm{ml} \mathrm{NH} \cdot \mathrm{H}_{2} \mathrm{O}(5 \%)$ was introduced into the mixture under stirring, the clear solution was transferred into a Teflon-lined steel-stainless autoclave of $40 \mathrm{ml}$. The autoclave was allowed to cool down to room temperature naturally after the system had been hydrothermally treated at $160^{\circ} \mathrm{C}$ for $6 \mathrm{~h}$. Black precipitates were collected, washed with distilled water and ethanol several times to remove impurities. Finally, the precipitates were dried in air at $50^{\circ} \mathrm{C}$ for $6 \mathrm{~h}$.

\section{Characterization of the samples}

Powder X-ray diffraction (XRD) of the product was carried out on a Shimadzu XRD-6000 X-ray diffractometer equipped with $\mathrm{Cu} K \alpha$ radiation $(\lambda=0.154060 \mathrm{~nm})$, employing a scanning rate of $0.02^{\circ} \mathrm{s}^{-1}$ and $2 \theta$ ranges from $20^{\circ}$ to $70^{\circ}$. Field emission scanning electron microscopes (SEM) was obtained by JEOL JSM-6700 FESEM (operating at $10 \mathrm{kV}$ ).

\section{Electrode modification}

The dispersed flower like $\mathrm{CuO}$ on the electrode were fabricated by the following way: Firstly, the glass carbon electrode (GCE, $\Phi=3 \mathrm{~mm}$ ) was polished with a $1700 \#$ diamond paper and washed successively with double distilled water and ethanol in an ultrasonic bath, then 15 cyclic scans were carried out in the potential of 2.0 
to $-2.0 \mathrm{~V}$ (vs. SCE) in the solution of $1.0 \mathrm{~mol} / \mathrm{l}_{2} \mathrm{SO}_{4}$. Secondly, $4 \mathrm{mg} \mathrm{CuO}$ was dispersed in $2 \mathrm{ml}$ ethanol solution. Then $20 \mu \mathrm{l}$ of $\mathrm{CuO}$ solution $(2 \mathrm{mg} / \mathrm{ml})$ was cast on the surface of GCE and dried in air. Thus flower like $\mathrm{CuO}$ modified GCE was obtained.

\section{Results and discussion}

\section{Structures and morphology characterization}

The morphology and micro-structure of the product were investigated by SEM. Figure $1(\mathrm{~A})$ and $1(\mathrm{~B}, \mathrm{C})$ are the SEM images of the sample. The low-magnification SEM image reveals that a large number of flower like $\mathrm{CuO}$ (Figure 1A) formed, composed of many nanoflake with average thickness of about $40 \mathrm{~nm}$ (Figure 1B, C), which may bring a favorite electronic property. Figure 1 (C) shows the typical XRD patterns of the as-synthesized products All diffractions can be indexed as monoclinic phased $\mathrm{CuO}$ by comparison with JCPDS card files No. $48-1548(\mathrm{a}=4.62 \AA, \mathrm{b}=3.43 \AA$, and $\mathrm{c}=5.06 \AA)$. No characteristic peaks of other impurities were detected.

\section{Electrochemical property of flower like CuO modified GCE} Figure 2 shows the cyclic voltammetric responses of various electrodes in an oxygen-free $0.1 \mathrm{M}$ phosphate buffer solution (PBS, pH 7.0). No redox peak was observed when the bare GCE was used as the work electrode (Figure 2a). While the $\mathrm{CuO} / \mathrm{GCE}$ was employed as the work electrode, a pair of well-defined redox peaks was obtained (Figure $2 \mathrm{~b}$ ) with an average formal potential of $-0.1895 \mathrm{~V}$. The cathodic peak and anodic peak were $-0.2820 \mathrm{~V}$ and $-0.0970 \mathrm{~V}$ at a scan rate of $0.05 \mathrm{~V} / \mathrm{s}$, respectively. Obviously, the redox peaks were attributed to the electrochemical reaction of $\mathrm{CuO}$. According to earlier reports [39], the cathodic peak corresponds to the reduction of $\mathrm{CuO} / \mathrm{Cu}_{2} \mathrm{O}$ redox couple, and the anodic peak comes from the formation of $\mathrm{CuO}$ layer.

\section{Electroreduction behavior and amperometric response of $\mathrm{H}_{2} \mathrm{O}_{2}$ on the $\mathrm{CuO} / \mathrm{GCE}$}

Figure 3(A) shows the cyclic voltammograms of the $\mathrm{CuO} / \mathrm{GCE}$ in the absence and presence of $\mathrm{H}_{2} \mathrm{O}_{2}$. When $\mathrm{H}_{2} \mathrm{O}_{2}$ was added to the $\mathrm{pH}$ 7.0 PBS, compared with the system with no $\mathrm{H}_{2} \mathrm{O}_{2}$ present (a), an obvious increase of the reduction peak was observed in deoxygenized environment (b, c). However, no electrochemical reduction peak was observed when the cyclic voltammetric scan was performed at bare GCE under the same conditions (Inset in Figure 3). The experimental results indicated that the $\mathrm{CuO} / \mathrm{GCE}$ exhibited excellent electrocatalytic activity to $\mathrm{H}_{2} \mathrm{O}_{2}$. Regarding the reduction peaks of $\mathrm{H}_{2} \mathrm{O}_{2}$ at $\mathrm{CuO} / \mathrm{GCE}$, the effect of potential scan rate was investigated clearly. As can been seen from Figure 3(B), the
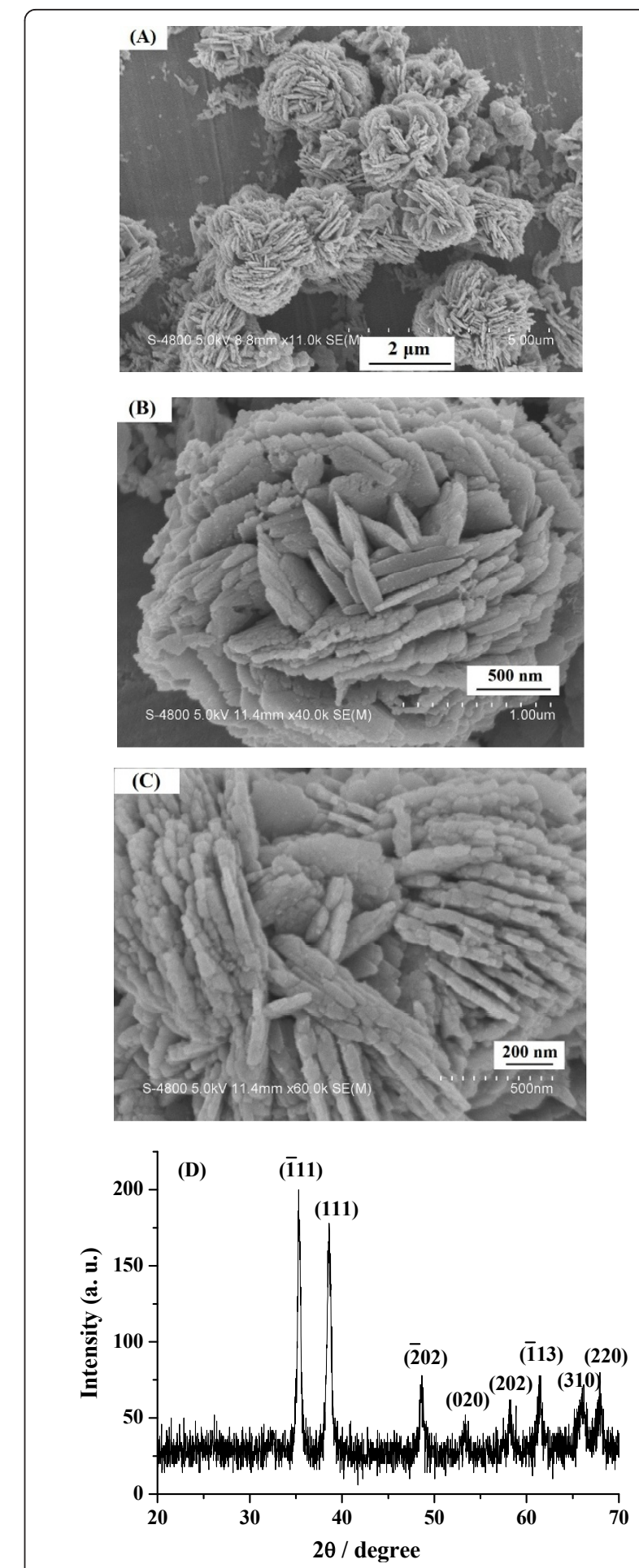

Figure 1 (A, B, C) SEM image and (D) the XRD pattern of the product.

reduction peak current is proportional to the square root of scan rate in the range of $30-200 \mathrm{mV} / \mathrm{s}, \mathrm{i}_{\mathrm{pa}} / \mu \mathrm{A}=$ $3.193+1.431 \mathrm{v}^{1 / 2} / \mathrm{mV} \cdot \mathrm{s}^{-1}, \mathrm{R}=0.9998$, indicating a diffusion controlled process [40]. 


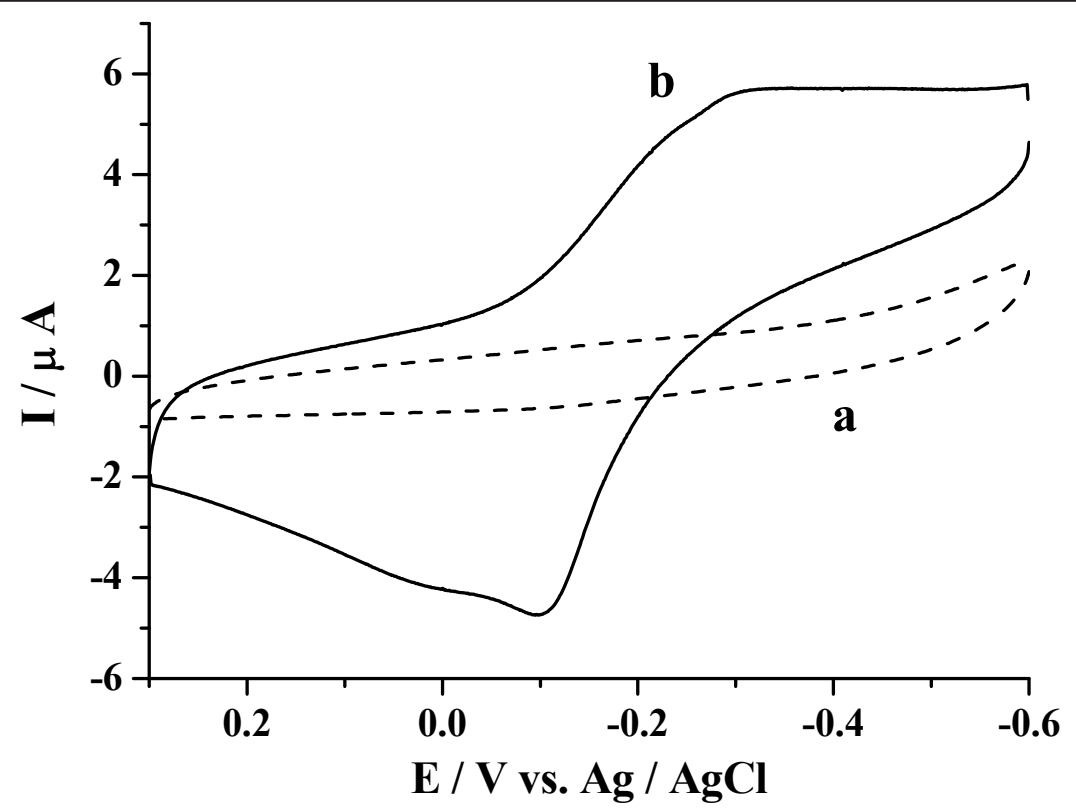

Figure 2 Cyclic voltammograms (CVs) recorded in an oxygen-free $0.1 \mathrm{M} \mathrm{PBS}(\mathrm{pH} 7.0$ ) at the scan rate of $0.05 \mathrm{~V} / \mathrm{s}$, using various modified electrodes: (a) bare GCE and (b) CuO/GCE.

The catalytic mechanism for the reduction of $\mathrm{H}_{2} \mathrm{O}_{2}$ can be assumed as $\mathrm{Cu}$ (II) was first electrochemically reduced to $\mathrm{Cu}$ (I), which reacted chemically with $\mathrm{H}_{2} \mathrm{O}_{2}$ and resulted in the conversion of $\mathrm{H}_{2} \mathrm{O}_{2}$ to $\mathrm{H}_{2} \mathrm{O}$ and in the regeneration of the catalyst [14].

Figure 4 illustrates current-time plots for the $\mathrm{CuO} /$ GCE with successive step changes of $\mathrm{H}_{2} \mathrm{O}_{2}$ concentration. As the $\mathrm{H}_{2} \mathrm{O}_{2}$ was injected into the stirring PBS, the steady-state currents reached another steady-state value (95\% of the maximum) in less than $3 \mathrm{~s}$. Such a fast response implies that the $\mathrm{CuO}$ can promote the oxidation of $\mathrm{H}_{2} \mathrm{O}_{2}$. The linear relationship between the catalytic current and the concentration is shown in the inset of the Figure 4. As can be seen, the $\mathrm{CuO} / \mathrm{GCE}$ displays linear response range of $5.0 \times 10^{-6}$ to $180.0 \times 10^{-6} \mathrm{M}$ (correlation coefficient: 0.9993 ), with a detection limit of $1.6 \times 10^{-6} \mathrm{M}$ at a signal-to-noise ratio of 3 , which is comparable or lower than detection limits obtained with protein $[22,41]$ or Ag nanoparticle $[42,43]$ based electrochemical sensors. We have summarized various $\mathrm{H}_{2} \mathrm{O}_{2}$ sensors in Table 1 with respect to the linear range and the detection limit. It can be seen that the performance of the noble metal Pt nanoparticle based sensor $[9,11,21]$ is excellent compared to the other material based electrode with respect to the linear range and the detection limit. Nevertheless, it should be noted that the detection limit achieved with the $\mathrm{CuO} / \mathrm{GCE}$ sensor was comparable or lower than that of protein or Ag nanoparticle based electrodes [41-43], and further $\mathrm{CuO}$ was prepared by a simple hydrothermal reaction and didn't require diffusional redox mediator and enzyme loading.

\section{Electrooxidation behavior and amperometric response of} $\mathrm{NO}_{2}^{-}$on the CuO/GCE

Figure 5(A) shows typical CVs of the $\mathrm{CuO} / \mathrm{GCE}$ in the absence and presence of $\mathrm{NO}_{2}^{-}$, at the scan rate of 0.05 $\mathrm{V} / \mathrm{s}$ in the oxygen-free $0.1 \mathrm{M} \mathrm{PBS}(\mathrm{pH} 7.0)$. A welldefined nitrite oxidation peak could be observed at ca. + $0.843 \mathrm{~V}$ vs. $\mathrm{Ag} / \mathrm{AgCl}$ (Figure 5(A) b, c), which is corresponding to the convertion of $\mathrm{NO}_{2}^{-}$to $\mathrm{NO}_{3}^{-}$through a two-electron oxidation process [44]. In contrast, no peak was observed when cyclic voltammogram of the same electrode was run in $0.1 \mathrm{M}$ phosphate buffer solution (PBS) (Figure 5(A) a). Cyclic voltammogram of the bare GCE was also run in the $1 \mathrm{mM} \mathrm{NO}_{2}^{-}$solution. The peak corresponding to the oxidation of nitrite appears at ca. $+1.038 \mathrm{~V}$ vs. $\mathrm{Ag} / \mathrm{AgCl}$ (Figure 5 (A) inset d), $195 \mathrm{mV}$ more positive potential than the one obtained for modified GCE, also being of smaller intensity. This result might be explained by $\mathrm{CuO}$ film providing abundant active sites improving the electrocatalytic activity for $\mathrm{NO}_{2}^{-}$. The catalytic oxidation mechanism can be explained with the following process:

$$
\begin{aligned}
& \mathrm{NO}_{2}^{-} \leftrightarrow 2 \mathrm{NO}_{2}+2 \mathrm{e}^{-} \\
& 2 \mathrm{NO}_{2}+\mathrm{H}_{2} \mathrm{O} \rightarrow \mathrm{NO}_{3}^{-}+\mathrm{NO}_{2}^{-}+2 \mathrm{H}^{+}
\end{aligned}
$$



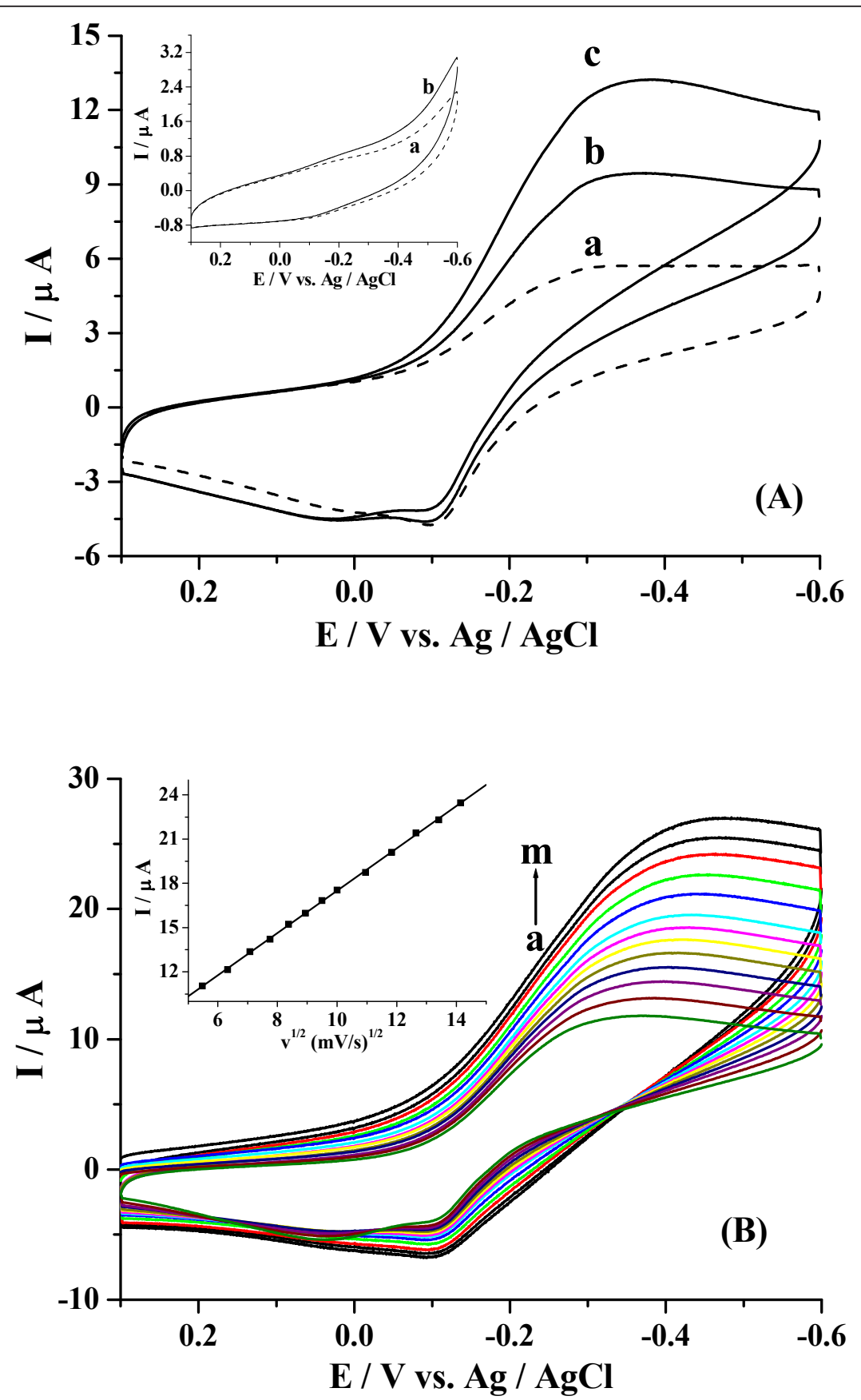

Figure 3 (A) CVs of $\mathrm{H}_{2} \mathrm{O}_{2}$ in $0.1 \mathrm{M}$ PBS of $\mathrm{pH} 7.0$ for CuO/GCE in various concentrations: (a) $0 \mathrm{mM}$, (b) $1 \mathrm{mM}$, (c) $2 \mathrm{mM}$ at scan rate of $50 \mathrm{mV} / \mathrm{s}$. Inset: $\mathrm{CVs}$ of $\mathrm{H}_{2} \mathrm{O}_{2}$ at bare GCE in various concentrations: (a) $0 \mathrm{mM}$, (b) $1 \mathrm{mM}$. (B) CVs of $2 \mathrm{mM} \mathrm{H}_{2} \mathrm{O}_{2}$ at the CuO/GCE in deoxygenized $0.1 \mathrm{M}$ PBS (pH 7.0) at different scan rates (from inside to outside: $\mathrm{a} \rightarrow \mathrm{m}: 0.03,0.04,0.05,0.06,0.07,0.08,0.09,0.10,0.12,0.14,0.16,0.18,0.20 \mathrm{~V} / \mathrm{s}$, respectively). The linear dependence of peak current with the square root of scan rate was shown in the inset.

$$
\mathrm{NO}_{2}^{-}+\mathrm{H}_{2} \mathrm{O} \rightarrow \mathrm{NO}_{3}^{-}+2 \mathrm{H}^{+}+2 e^{-}
$$

First, nitrite loses an electron to form $\mathrm{NO}_{2}$ [reaction (1)]. Second, this step is followed by a homogeneous disproportionation [reaction (2)] of $\mathrm{NO}_{2}$ into nitrate and nitrite, which can be written as the total reaction (3) $[45,46]$.

Regarding the oxidation peak of $\mathrm{NO}_{2}^{-}$at $\mathrm{CuO} / \mathrm{GCE}$, the potential scan rate was investigated clearly as shown in Figure 5(B). The peak current is proportional to the square root of scan rate in the range of $10-200 \mathrm{mV} / \mathrm{s}$, 


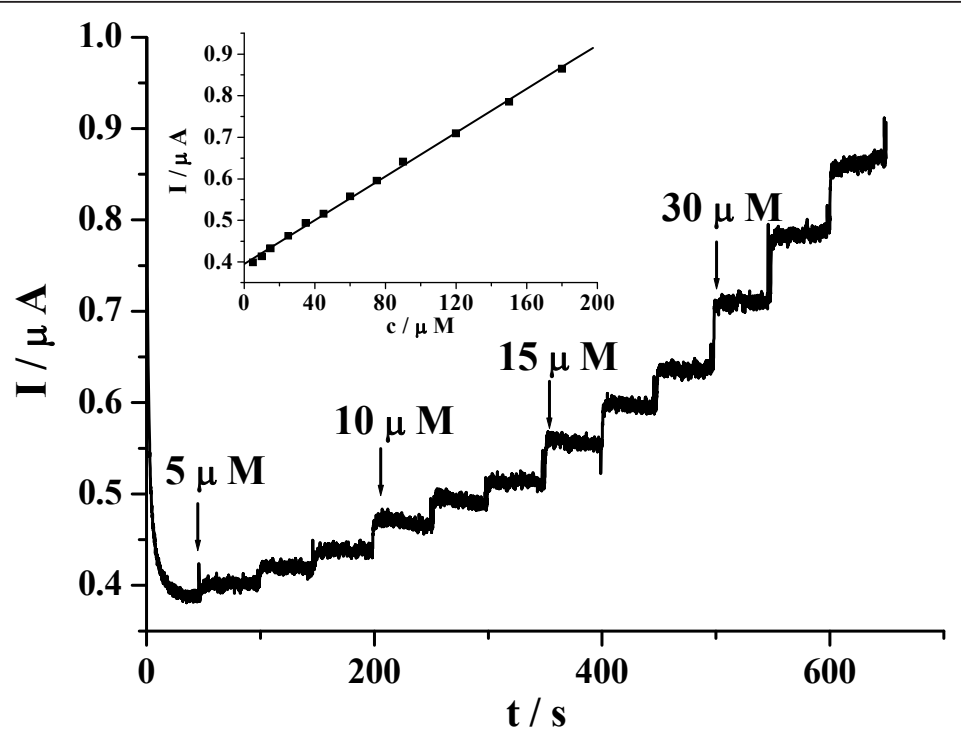

Figure 4 Amperometric responses of $\mathrm{CuO} / \mathrm{GCE}$ upon the successive addition of $\mathrm{H}_{2} \mathrm{O}_{2}$ into gently stirred $0.1 \mathrm{M}$ PBS at $-0.20 \mathrm{~V}$. Inset: the linear relationships between the catalytic current and the concentration.

$\mathrm{i}_{\mathrm{pa}} / \mu \mathrm{A}=-3.5542-1.9517 \mathrm{v}^{1 / 2} / \mathrm{mV} \cdot \mathrm{s}^{-1}, \mathrm{R}=0.9995$, while the $\mathrm{E}_{\mathrm{pa}}$ shifted positively. The results suggested that the oxidation of $\mathrm{NO}_{2}^{-}$was undergoing a diffusion controlled process [40].

Figure 6 illustrates current-time plots for the $\mathrm{CuO} /$ GCE under the optimized experimental conditions with successive step changes of $\mathrm{NO}_{2}^{-}$concentration. As the $\mathrm{NO}_{2}^{-}$was injected into the stirring PBS, the steady-state currents reached another steady-state value (95\% of the maximum) in less than $3 \mathrm{~s}$. Such a fast response implies that the $\mathrm{CuO}$ can promote the oxidation of $\mathrm{NO}_{2}^{-}$. The linear relationship between the catalytic current and the concentration is shown in the inset of the Figure 6. As can be seen, the $\mathrm{CuO} / \mathrm{GCE}$ displays linear response range of $1.0 \times 10^{-6}$ to $91.5 \times 10^{-6} \mathrm{M}$ (correlation coefficient: 0.9994), with a detection limit of $3.6 \times 10^{-7} \mathrm{M}$ at a signal-to-noise ratio of 3 and a sensitivity of $-25.53 \mu \mathrm{A} /$ $\mathrm{mM}$. Note that the obtained detection limit of $3.6 \times 10^{-7}$ $\mathrm{M}$ is comparable or lower than those obtained with other electrochemical methods [30,31,47-50]. We have summarized various $\mathrm{NO}_{2}^{-}$sensors in Table 2 with respect to the linear range and the detection limit. Compared with other reported values [30,31,47-50] in Table 2 , $\mathrm{CuO} / \mathrm{GCE}$ exhibits the comparable or lower detection limit but narrower linear range.

The potential interference for the detection of nitrite using this electrochemical sensor was also examined by adding the following ions into the PBS solution at the same concentration that was used for nitrite: $\mathrm{K}^{+}, \mathrm{Na}^{+}$, $\mathrm{Mg}^{2+}, \mathrm{Zn}^{2+}, \mathrm{Cl}^{-}, \mathrm{SO}_{4}^{2-}$ and $\mathrm{PO}_{4}^{3-}$. None of the ions caused interference. The potential of nitrite oxidation is high and, as a result, other electroactive species present in complex like dopamine and ascorbic acid can in principle be oxidized as well, interfering with the nitrite analysis. However, the detection of nitrite was examined in presence of 20-fold amount of dopamine and ascorbic acid and showed no interference. This result is similar to that of the previous report [30], which demonstrates

Table 1 Comparison of performances of different electrochemical sensors for hydrogen peroxide.

\begin{tabular}{cccc}
\hline Electrode & Linear range & Detection limit & Reference \\
\hline Pt-nanoparticle GCE & $0.5 \mathrm{nM}-4 \mathrm{mM}$ & $0.5 \mathrm{nM}$ & {$[9]$} \\
Graphene-Pt nanoparticle-GCE & $0.5-12 \mathrm{mM}$ & $0.5 \mathrm{nM}$ & {$[11]$} \\
Enzyme integrated silicate-Pt nanoparticle & & $0.5 \mathrm{nM}$ & {$[21]$} \\
Redox protein based EC & $0.25-50 \mu \mathrm{M}$ & $0.25 \mu \mathrm{M}$ & {$[22]$} \\
Hb-kieselgubr EC & $5.0-300 \mu \mathrm{M}$ & $2.1 \mu \mathrm{M}$ & {$[41]$} \\
Ag microspheres-GCE & $0.2-2.0 \mathrm{mM}$ & $1.2 \mu \mathrm{M}$ & $1.7 \mu \mathrm{M}$ \\
Ag-nano-DNA GCE & $4.0 \mu \mathrm{M}-16.0 \mathrm{mM}$ & $1.6 \mu \mathrm{M}$ & {$[42]$} \\
CuO-GCE & $5.0-180.0 \mu \mathrm{M}$ & This work \\
\hline
\end{tabular}



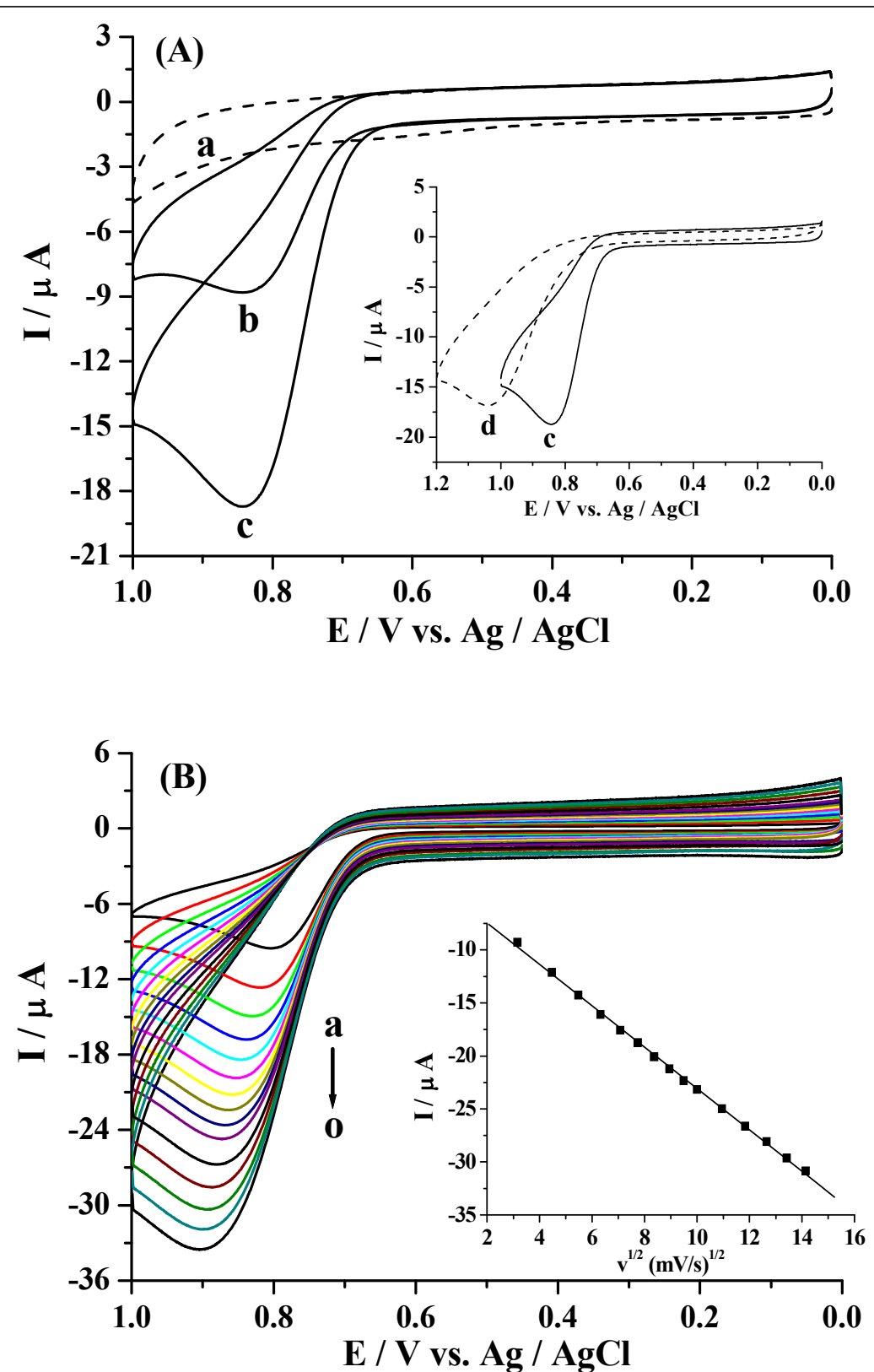

Figure 5 (A) $\mathrm{CVs}_{\mathrm{s}}$ of $\mathrm{NO}_{2}^{-}$in $0.1 \mathrm{M}$ PBS of $\mathrm{pH} 7.0$ for CuO/GCE in various concentrations: (a) $0 \mathrm{mM}$, (b) $0.5 \mathrm{mM}$, (c) $1 \mathrm{mM}$ at the scan rate of $50 \mathrm{mV} / \mathrm{s}$. Inset: $\mathrm{CVs}_{2}$ of $1 \mathrm{mM} \mathrm{NO} \mathrm{NO}_{2}^{-}$at CUO/GCE (c) and bare GCE (d) in the same condition. (B) CVs of $1 \mathrm{mM} \mathrm{NO}-$ at the CuO/GCE in deoxygenized 0.1 M PBS (pH 7.0) at different scan rates (from inside to outside: a $\rightarrow 0: 0.01,0.02,0.03,0.04,0.05,0.06,0.07,0.08,0.09,0.10$, $0.12,0.14,0.16,0.18,0.20 \mathrm{~V} / \mathrm{s}$, respectively). The linear dependence of peak current with the square root of scan rate was shown in the inset.

the selectivity of $\mathrm{CuO}$ based electrochemical sensor towards nitrite.

\section{Conclusions}

In summary, flower like $\mathrm{CuO}$ composed of many nanoflake with average thickness of $40 \mathrm{~nm}$ was synthesized by a simple hydrothermal reaction. Then a novel electrochemical sensor made of $\mathrm{CuO}$ onto GCE had been constructed. Due to the large specific surface area and inner characteristic of the flower like $\mathrm{CuO}$, the resulting electrode show excellent electrocatalytic reduction for $\mathrm{H}_{2} \mathrm{O}_{2}$ and oxidation of $\mathrm{NO}_{2}^{-}$. Its sensitivity, low detection limit, fast response time and simplicity are satisfactory. Furthermore, this synthetic approach can also be applied for the synthesis of other inorganic oxides with improved performances and they can also be extended to construct other micro/nano-structured functional surfaces. 


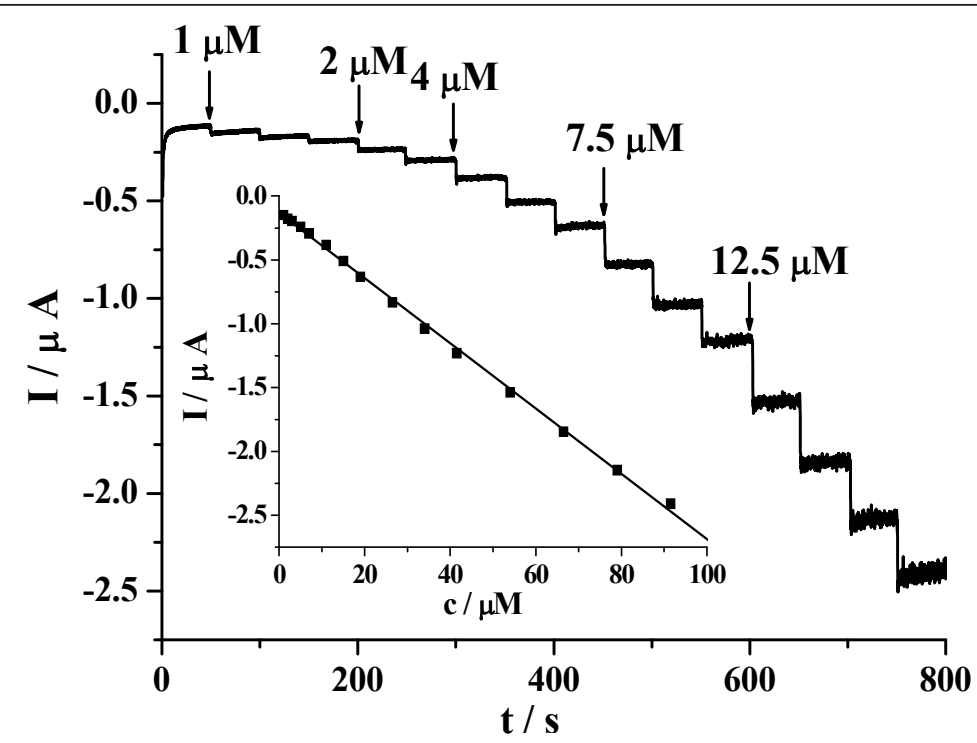

Figure 6 Amperometric responses of CuO/GCE upon the successive addition of $\mathrm{NO}_{2}^{-}$into gently stirred $0.1 \mathrm{M}$ PBS at $0.85 \mathrm{~V}$. Inset: the linear relationships between the catalytic current and the concentration.

Table 2 Comparison of performances of different electrochemical sensors for nitrites.

\begin{tabular}{cccc}
\hline Electrode & Linear range $(\mu \mathrm{M})$ & Detection limit $(\mu \mathrm{M})$ & Reference \\
\hline Nano-Au/Ch/GC & $0.4-750$ & 0.1 & {$[47]$} \\
Nano-Au/P3MT/GC & $5-500$ & 2.3 & {$[48]$} \\
Pt disk electrode & $10-10000$ & 4.8 & {$[49]$} \\
$\mathrm{Cu}-\mathrm{Tl}$ composite film-GCE & $1000-10000$ & 250 & {$[50]$} \\
$\mathrm{CuO}-$-Graphite Composite EC & $100-1250$ & 0.6 & {$[30]$} \\
$\mathrm{MnO}_{2}$-Graphite Composite EC & & 1.2 & {$[31]$} \\
CuO-GCE & $1.0-91.5$ & 0.36 & This work \\
\hline
\end{tabular}

\section{Acknowledgements}

The authors thank the National Natural Science Foundation of China (21001004), Young Fund of Anhui Normal University (2008xqn61) for fund support. This work is also supported by the innovation lab platform of Anhui Normal University.

\section{Authors' contributions}

LZ completed the electrochemical work, data treatment and drafted the manuscript. FY participated in data analysis. XZ carried out the work of preparation, participated in data collection. LY participated in data analysis. All authors have read and approved the final manuscript.

\section{Competing interests}

The authors declare that they have no competing interests.

Received: 17 September 2011 Accepted: 2 December 2011 Published: 2 December 2011

\section{References}

1. Yao $S, X u$ J, Wang $Y$, Chen $X, X u Y$, Hu S: A highly sensitive hydrogen peroxide amperometric sensor based on $\mathrm{MnO}_{2}$ nanoparticles and dihexadecyl hydrogen phosphate composite film. Anal. Chim. Acta 2006, 557:78-84.

2. Hurdis EC, Romeyn HJ: Accuracy of Determination of Hydrogen Peroxide by Cerate Oxidimetry. Anal Chem 1954, 26(2):320-325.
3. Lobnik A, Cajlakovic M: Sol-gel based optical sensor for continuous determination of dissolved hydrogen peroxide. Sens Actuators B: Chem 2001, 74:194-199.

4. Pinkernell U, Effkemann S, Karst U: Simultaneous HPLC determination of peroxyacetic acid and hydrogen peroxide. Anal Chem 1997, 69:3623-3627.

5. Rocha FRP, Torralba ER, Reis BF, Rubio AM, Guardia M: A portable and low cost equipment for flow injection chemiluminescence measurements. Talanta 2005, 67:673-677.

6. Wang L, Wang E: A novel hydrogen peroxide sensor based on horseradish peroxidase immobilized on colloidal Au modified ITO electrode. Electrochem Commun 2004, 67:225-229.

7. Qin X, Wang H, Wang X, Miao Z, Fang Y, Chen Q, Shao X: Synthesis of dendritic silver nanostructures and their application in hydrogen peroxide electroreduction. Electrochim Acta 2011, 56:3170-3174.

8. Polsky R, Gill R, Kaganovsky L, Willner I: Electrochemical Detection of Biomolecules. Anal Chem 2006, 67:2268-2271.

9. Chakraborty $S$, Raj CR: Pt nanoparticle-based highly sensitive platform for the enzyme-free amperometric sensing of $\mathrm{H}_{2} \mathrm{O}_{2}$. Biosen Bioelectron 2009, 24:3264-3268.

10. Huang J, Wang D, Hou H, You T: Electrospun Palladium NanoparticleLoaded Carbon Nanofibers and Their Electrocatalytic Activities towards Hydrogen Peroxide and NADH. Adv Funct Mater 2008, 18:441-448.

11. Dey RS, Raj CR: Development of an Amperometric Cholesterol Biosensor Based on Graphene-Pt Nanoparticle Hybrid Material. J Phys Chem C 2010, 114:21427-21433.

12. Lin YH, Cui XL, Li LY: Low-potential amperometric determination of hydrogen peroxide with a carbon paste electrode modified with 
nanostructured cryptomelane-type manganese oxides. Electrochem Commun 2005, 7:166-172.

13. Liu S, Li L, Hao Q, Yin X, Zhang M, Li Q, Chen L, Wang T: A novel nonenzymatic hydrogen peroxide sensor based on Mn-nitrilotriacetate acid (Mn-NTA) nanowires. Talanta 2010, 81:727-731.

14. Miao XM, Yuan R, Chai YQ, Shi YT, Yuan YY: Direct electrocatalytic reduction of hydrogen peroxide based on Nafion and copper oxide nanoparticles modified Pt electrode. J Electroanal Chem 2008, 612:157-163.

15. Gu A, Wang G, Gu J, Zhang $X$, Fang B: An unusual $\mathrm{H}_{2} \mathrm{O}_{2}$ electrochemical sensor based on $\mathrm{Ni}(\mathrm{OH})_{2}$ nanoplates grown on Cu substrate. Electrochim. Acta 2010, 55:7182-7187.

16. Li MG, Chen SH, Ni F, Wang YL, Wang L: Layered double hydroxides functionalized with anionic surfactant: Direct electrochemistry and electrocatalysis of hemoglobin. Electrochim Acta 2008, 53:7255-7260.

17. Ricci F, Amine A, Tuta CS, Ciucu AA, Lucarelli F, Palleschi G, Moscone D: Prussian Blue and enzyme bulk-modified screen-printed electrodes for hydrogen peroxide and glucose determination with improved storage and operational stability. Anal Chim Acta 2003, 485:111-120.

18. Lu Q, Zhou T, Hu SS: Direct electrochemistry of hemoglobin in PHEA and its catalysis to $\mathrm{H}_{2} \mathrm{O}_{2}$. Biosens Bioelectron 2007, 22(6):899-904.

19. $\mathrm{Xu} B, \mathrm{Ye} M L, Y u Y X$, Zhang WD: A highly sensitive hydrogen peroxide amperometric sensor based on $\mathrm{MnO}_{2}$-modified vertically aligned multiwalled carbon nanotubes. Analy Chim Acta 2010, 674:20-26.

20. Liu S, Tian J, Wang L, Sun X: A method for the production of reduced graphene oxide using benzylamine as a reducing and stabilizing agent and its subsequent decoration with Ag nanoparticles for enzymeless hydrogen peroxide detection. Carbon 2011, 49:3158-3164.

21. Jena BK, Raj CR: Enzyme integrated silicate-Pt nanoparticle architecture: A versatile biosensing platform. Biosen Bioelectron 2011, 67:2960-2966.

22. Behera S, Raj CR: Mercaptoethylpyrazine promoted electrochemistry of redox protein and amperometric biosensing of uric acid. Biosen Bioelectron 2007, 67:556-561.

23. Huang YG, Ji JD, Hou QN: A study on carcinogenesis of endogenous nitrite and nitrosamine, and prevention of cancer. Mutat Res 1996, 358:7-14.

24. Davis J, McKeegan KJ, Cardosi MF, Vaughan DH: Evaluation of phenolic assays for the detection of nitrite. Talanta 1999, 50(1):103-112.

25. Davis J, Moorcroft MJ, Wilkins SJ, Compton RG, Cardosi MF: Electrochemical detection of nitrate and nitrite at a copper modified electrode. Analyst 2000, 67:737-742.

26. Moorcroft MJ, Davis J, Compton RG: Detection and determination of nitrate and nitrite: a review. Talanta 2001, 54(5):785-803.

27. Lijinsky W, Epstein SS: Nitrosamines as environmental carcinogens. Nature 1970, 225:21-23.

28. Wolf IA, Wasserman AE: Nitrates, nitrites, and nitrosamines. Science 1972, 177:15-19.

29. Cao X, Wang N, Guo L: Facile synthesis of novel $\mathrm{MnO}_{2}$ hierarchical nanostructures and their application to nitrite sensing. Sens. Actuators B: Chem 2009, 137:710-714.

30. Šljukic B, Banks CE, Crossley An, Compton RG: Copper Oxide-Graphite Composite Electrodes: Application to Nitrite Sensing. Electroanalysis 2007, 19(1):79-84.

31. Langley CE, Šljukic B, Banks CE, Compton RG: Manganese Dioxide Graphite Composite Electrodes: Application to the Electroanalysis of Hydrogen Peroxide, Ascorbic Acid and Nitrite. Analytical Sciences 2007, 67:165-170.

32. Patil SA, Patil LA, Patil DR, Jain GH, Wagh MS: CuO-doped BSST thick film resistors for ppb level $\mathrm{H}_{2} \mathrm{~S}$ gas sensing at room temperature. Sens Actuat B 2007, 123(1):246-253

33. Vastarellaa W, Nicastrib R: Enzyme/semiconductor nanoclusters combined systems for novel amperometric biosensors. Talanta 2005, 66(3):627-633.

34. Liu ZG, Zhou RX, Zheng XM: Comparative study of different methods of preparing $\mathrm{CuO}-\mathrm{CeO}_{2}$ catalysts for preferential oxidation of $\mathrm{CO}$ in excess hydrogen. J Mol Catal A-Chem 2007, 267(1-2):137-142.

35. Luque GL, Rodriguez MC, Rivas GA: Glucose biosensors based on the immobilization of copper oxide and glucose oxidase within a carbon paste matrix. Talanta 2005, 66(2):467-471.

36. Li Y, Zhang Q, Li J: Direct electrochemistry of hemoglobin immobilized in CuO nanowire bundles. Talanta 2010, 83(1):162-166.
37. Zhang L, Li H, Ni YH, Li J, Liao KM, Zhao GC: Porous cuprous oxide microcubes for non-enzymatic amperometric hydrogen peroxide and glucose sensing. Electrochem Comm 2009, 11:812-815.

38. Zhang L, Ni YH, Wang XH, Zhao GC: Direct electrocatalytic oxidation of nitric oxide and reduction of hydrogen peroxide based on $\mathrm{a}-\mathrm{Fe}_{2} \mathrm{O}_{3}$ nanoparticles-chitosan composite. Talanta 2010, 82:196-201.

39. Zen J, Chung H, Kumar AS: Flow injection analysis of hydrogen peroxide on copper-plated screen-printed carbon electrodes. Analyst 2000, 125:1633-1637.

40. Engel D, Grabner EW: Copper Hexacyanoferrate-Modified Glassy Carbon: A Novel Type of Potassium-Selective Electrode. Ber Bunsenges Phys Chem 1985, 89:982-986.

41. Wang HY, Guan R, Fan CH, Zhu DX, Li GX: A hydrogen peroxide biosensor based on the bioelectrocatalysis of hemoglobin incorporated in a kieselgubr film. Sens Actuators B: Chem 2002, 84:214-218.

42. Zhao B, Liu Z, Liu G, Li Z, Wang J, Dong X: Silver microspheres for application as hydrogen peroxide sensor. Electrochem Commun 2009, 11(8):1707-1710.

43. Cui $K$, Song $Y H$, Yao $Y$, Huang ZZ, Wang L: A novel hydrogen peroxide sensor based on Ag nanoparticles electrodeposited on DNA-networks modified glassy carbon electrode. Electrochem Commun 2008, 10(4):663-667.

44. Zhu NN, Xu Q, Li S, Gao H: Electrochemical determination of nitrite based on poly(amidoamine) dendrimer-modified carbon nanotubes for nitrite oxidation. Electrochem Commun 2009, 11(12):2308-2311.

45. Guidelli R, Pergola F, Raspi G: Voltammetric behavior of nitrite ion on platinum in neutral and weakly acidic media. Anal Chem 1972, 44:745-755.

46. Yu C, Guo J, Gub H: Electrocatalytical Oxidation of Nitrite and Its Determination Based on $\mathrm{Au} @ \mathrm{Fe}_{3} \mathrm{O}_{4}$ Nanoparticles. Electroanalysis 2010, 67:1005-1011.

47. Wang P, Mai ZB, Dai Z, Li YX, Zou XY: Construction of Au nanoparticles on choline chloride modified glassy carbon electrode for sensitive detection of nitrite. Biosens Bioelectron 2009, 24:3242-3247.

48. Huang X, Li YX, Chen YL, Wang L: Electrochemical determination of nitrite and iodate by use of gold nanoparticles/poly(3-methylthiophene) composites coated glassy carbon electrode. Sens Actuators B 2008, 67:780-786.

49. Abbaspour A, Mehrgardi MA: Electrocatalytic activity of Ce(III)-EDTA complex toward the oxidation of nitrite ion. Talanta 2005, 67(3):579-584.

50. Casella IG, Gatta MM: Electrochemical reduction of $\mathrm{NO}_{3}^{-}$and $\mathrm{NO}_{2}^{-}$ on a composite copper thallium electrode in alkaline solutions. $J$ Electroanal Chem 2004, 568:183-188.

doi:10.1186/1752-153X-5-75

Cite this article as: Zhang et al:: Facile synthesis of flower like copper oxide and their application to hydrogen peroxide and nitrite sensing. Chemistry Central Journal 2011 5:75.

\section{Publish with ChemistryCentral and every scientist can read your work free of charge \\ "Open access provides opportunities to our colleagues in other parts of the globe, by allowing anyone to view the content free of charge." W. Jeffery Hurst, The Hershey Company.}

- available free of charge to the entire scientific community

- peer reviewed and published immediately upon acceptance

- cited in PubMed and archived on PubMed Central

- yours - you keep the copyright

Submit your manuscript here:

http://www.chemistrycentral.com/manuscript/<smiles>c1ccccc1</smiles>

ChemistryCentral 